\title{
Basit Elektrik Devresinde Lamba Parlaklığını Etkileyen Değişkenlerin Hidrolik Sistem Modeli (HSM) Kullanılarak Öğretimi
}

\section{Gonca HARMAN*}

Makale Gönderme Tarihi: 10.10.2016

Makale Kabul Tarihi: 17.01.2017

Özet - Bir analoji olan Hidrolik Sistem Modeli (HSM) basit elektrik devresinde lamba parlaklığı üzerinde etkili olan faktörlerin öğretiminde kullanılmak üzere hazırlanmıştır. Model serum torbası, plastik şeffaf borular, vana, plastik pet şişe, kırmızı alüminyum folyodan yapılmış top gibi atık materyaller kullanılarak hazırlanmıştır. Çalışmada basit elektrik devresi ile HSM arasında "Lamba (plastik pet şişe) sayısı sabit olmak üzere devreye bir pil (serum torbasının içindeki su miktarı) daha seri bağlı olarak eklenirse lamba parlaklı̆̆ı (topun yüksekliği) artar." ve "Pil (serum torbasının içindeki su miktarı) sayısı sabit olmak üzere devreye bir lamba (plastik pet şişe) daha seri bağlı olarak eklenirse lamba parlaklığı (topun yüksekliği) azalır.” olmak üzere analojik ilişki kurulmuştur. Ayrıca bağımlı, bağımsız ve kontrol edilen değişkenler HSM üzerinde gösterilmiştir. HSM ve basit elektrik devresinde gerçekleşen enerji dönüşümleri de ifade edilmiştir. Kavram yanılgısı oluşumunu önlemek için kaynak ve hedef kavramlar arasındaki benzerlikler ve farklılıklar belirtilmiştir. HSM'nin atık materyaller kullanılarak hazırlanması nedeni ile geri dönüşüm, yeniden kullanım ve geri kazanımın öğretimde de önemli olacağı düşünülmektedir.

Anahtar kelimeler: analoji, basit elektrik devresi, lamba parlaklı̆̆ı, hidrolik sistem modeli.

\section{Genişletilmiş Özet}

Günlük yaşamın olmazsa olmaz bir unsuru olan elektrik ilkokuldan başlanılarak fen bilimleri ile ilgili eğitim programlarını içeren yüksek öğretim kurumları da dahil olmak üzere öğrencilerin öğrenmede güçlük yaşadığı ve oldukça dirençli kavram yanılgılarına sahip olduğu bir konudur. Öğrenme güçlükleri ve kavram yanılgıları konunun öğretiminde basit elektrik devresi ile birlikte alternatif modellerin kullanımını gerekli kılmaktadır. Bu gereklilik dikkate alınarak çalışmada basit elektrik devresi ile eş zamanlı olarak kullanılabilecek bir model geliştirilmiştir.

\footnotetext{
* İletişimden Sorumlu Yazar: Dr. Gonca HARMAN

E-mail: goncaharman@hotmail.com
} 
Basit elektrik devresinde lamba parlaklığı üzerinde etkili olan faktörlerin öğretiminde kullanılmak üzere geliştirilen model su ile çalışan bir sistem olması nedeni ile Hidrolik Sistem Modeli olarak adlandırılmıştır. Hidrolik Sistem Modeli serum torbası, plastik şeffaf borular, vana, plastik pet şişe, kırmızı alüminyum folyodan yapılmış top gibi atık materyaller kullanılarak hazırlanmıştır. Hidrolik Sistem Modeli ve basit elektrik devresi arasında serum torbasının içindeki su miktarı: pil, plastik şeffaf borular: bağlantı kablosu, vana: anahtar, plastik pet şişe: lamba, plastik pet şişe içindeki kırmızı topun yüksekliği: lamba parlaklığı olmak üzere kaynak ve hedef kavramlar arasında analojik ilişki kurulmuştur.

Deneysel temelli Hidrolik Sistem Modeli üzerine kurulu etkinlik üç aşamada gerçekleştirilmiştir.

Birinci aşamada: Hidrolik Sistem Modeli ile basit bir elektrik devresinde lamba parlaklığını etkileyen değişkenlerin öğretimi için kaynak ve hedef arasında analojik ilişki kurmak amaçlanmıştır.

İkinci aşamada: Lamba sayısı sabit olmak üzere pil sayısındaki artışın, lamba parlaklığı üzerindeki etkisi ile plastik pet şişe sayısı sabit olmak üzere serum torbasındaki su miktarındaki artışın plastik pet şişenin içindeki topun yükselmesi üzerindeki etkisi arasında analojik bir ilişki kurmak amaçlanmıştır.

Üçüncü aşamada: Pil sayısı sabit olmak üzere lamba sayısındaki artışın, lamba parlaklığı üzerindeki etkisi ile serum torbasındaki su miktarı sabit olmak üzere plastik pet şişe sayısındaki artışın plastik pet şişenin içindeki topun yükselmesi üzerindeki etkisi arasında analojik bir ilişki kurmak amaçlanmıştır.

"Serum torbasının sisteme verdiği su (pilin potansiyeli) plastik şeffaf hortum (bağlantı kablosu) ile plastik pet şişeye (lambaya) ulaşır ve top yükselir (lamba yanar). Toplarda gerçekleşecek yükselme (lambanın parlaklı̆̆l) plastik pet şişe sayısı (lamba sayısı) ve serum torbasındaki suyun miktarına (pil sayısına) bağlı olarak değişir.” olmak üzere analojik ilişki ifade edilmiştir. "Lamba (plastik pet şişe) sayısı sabit olmak üzere devreye bir pil (serum torbasının içindeki su miktarl) daha seri bağlı olarak eklenirse lamba parlaklı̆̆ (topun yüksekliği) artar." ve "Pil (serum torbasının içindeki su miktarı) sayısı sabit olmak üzere devreye bir lamba (plastik pet şişe) daha seri bağlı olarak eklenirse lamba parlakliğı (topun yüksekliği) azalır." şeklinde sonuç çıkarılmıştır. Ayrıca bağımlı, bağımsız ve kontrol edilen değişkenler Hidrolik Sistem Modeli ile basit elektrik devresi arasında yapılan karşılaştırmalarla ifade edilmiştir. Hidrolik Sistem Modeli 1 (basit elektrik devresi 1) ile Hidrolik Sistem Modeli 2 (basit elektrik devresi 2) arasında değişken türleri bağlamında 
yapılan karşılaştırma için bağımlı değişken plastik pet şişe içindeki kırmızı topun yüksekliği (lamba parlaklığı), bağımsız değişken serum torbasının içindeki su miktarı (pil sayısı) ve kontrol edilen değişken plastik pet şişe sayısı (lamba sayısı) olarak ifade edilmiştir. Hidrolik Sistem Modeli 2 (basit elektrik devresi 2) ile Hidrolik Sistem Modeli 3 (basit elektrik devresi 3) arasında değişken türleri bağlamında yapılan karşılaştırma için bağımlı değişken plastik pet şişe içindeki kırmızı topun yüksekliği (lamba parlaklığı), bağımsız değişken plastik pet şişe sayısı (lamba sayısı) ve kontrol edilen değişken serum torbasının içindeki su miktarı (pil sayısı) olarak ifade edilmiştir. Çalışmada Hidrolik Sistem Modeli ve basit elektrik devresinde gerçekleşen enerji dönüşümleri de ifade edilmiştir. Basit elektrik devresinde gerçekleşen enerji dönüşümü için pilde elektrik enerjisi kimyasal enerjiye dönüşürken lambada elektrik enerjisi 1sı ve 1şık enerjisine dönüşür. Hidrolik Sistem Modelinde gerçekleşen enerji dönüşümü için serum torbasındaki suyun potansiyel enerjisi kinetik enerjiye dönüşürken suyun kinetik enerjisi topun potansiyel ve kinetik enerjisine dönüşür. Ayrıca kavram yanılgısı oluşumunu önlemek için kaynak ve hedef kavramlar arasındaki benzerlikler ve farklılıklar belirtilmiştir. Kaynak-hedef kavram arasındaki farklılıklar "Basit elektrik devresinde elektrik akımı pile geri dönerken Hidrolik Sistem Modelinde su serum torbasına geri dönmez. Basit elektrik devresinde lambanın yanması için anahtar kapalı, Hidrolik Sistem Modelinde suyun etkisi ile topların yükselmesi için vana açık olmalıdır." olarak ifade edilmiştir.

Deneysel temelli Hidrolik Sistem Modeli ile öğrenciler basit bir elektrik devresinde lamba parlaklığını etkileyen değişkenleri bağımlı, bağımsız ve kontrol edilebilen değişken şeklinde ortaya koyabilmekte, tahmin, gözlem, veri toplama, deney yapma, problem çözme ve model oluşturma gibi bilimsel süreç becerilerini geliştirebilmektedir. $\mathrm{Bu}$ çalışma kapsamında geliştirilen ve seri bağlı devreler için uygun olan model basit elektrik devresi ile birlikte konunun öğretiminde alternatif bir etkinlik olarak kullanılabilir. Bunların yanı sıra Hidrolik Sistem Modelinin kolay temin edilebilecek türden atık materyaller kullanılarak hazırlanması nedeni ile geri dönüşüm, yeniden kullanım ve geri kazanıma dikkat çekme bağlamında da etkili olacağı düşünülmektedir. Ayrıca Hidrolik Sistem Modeli çalışan bir sistem olup zaman ve maliyet açısından son derece ekonomiktir. Hazırlanması oldukça kolay olan bu modeli öğrenciler kendi başlarına hem evlerinde hem de okullarında kurabilirler. 


\title{
Teaching the Variables Affecting on the Brightness of a Light Bulb in a Simple Electrical Circuit Using a Hydraulic System Model (HSM)
}

\author{
Gonca HARMAN1
}

Received : 10.10.2016

Accepted : 17.01.2017

\begin{abstract}
Hydraulic system model (HSM) is an analogy. HSM was prepared for the teaching variables that affect the brightness of a bulb in a simple electrical circuit. Waste materials such as serum bag, plastic transparent hose, valve, plastic PET bottle, ball made of red aluminum foil were used to prepare HSM. Analogical relationship between a simple electrical circuit and HSM was established. When number of the bulb (plastic PET bottle) remain constant and a battery (amount of water in serum bag) is added in series circuit (in HSM), the brightness of a bulb (the height of the red ball) increases. When number of the battery (amount of water in serum bag) remain constant and a bulb (plastic PET bottle) is added in series circuit (in HSM), the brightness of a bulb (the height of the red ball) decreases. Dependent, independent and controlled variables were shown on the Hydraulic System Model (HSM). Conversion energy was explained in the HSM and simple electrical circuit. The differences and similarities between the source and target concepts were expressed for identifying and remedying misconceptions. Waste materials were used for preparing HSM. Therefore, HSM is important model for teaching recycling, reuse and recovery of waste material.
\end{abstract}

Key words: analogy, a simple electrical circuit, the brightness of a bulb, hydraulic system model.

\section{Introduction}

Electricity is a basic and an important topic of science and physics educations. Major concepts of electricity are systematically taught in science and physics classes at all levels of education from primary school to university. Whereas, it is known that students have misconceptions and difficulties on understanding and learning the concepts of electricity. These misconceptions are expressed some models i.e. sink theory (unipolar model), clashing currents (two-component) model, current consumption model, local and sequential reasoning model, emprical rule model, constant current source model. These misconceptions create misconceptions about the brightness of a bulb.

\footnotetext{
${ }^{1}$ Corresponding author: Dr. Gonca HARMAN

E-mail: goncaharman@hotmail.com 


\section{Sink Theory (Unipolar Model)}

Students believed that one wire between bulb and battery is enough to complete circuit and bulb produces light (Çepni \& Keleş, 2006; Bakırcı et al., 2010; Dupin \& Johsua, 1987; Fleer, 1994; Keser \& Başak, 2013; Yıldırım et al., 2008; Yılmaz \& Huyugüzel-Çavaş, 2006; Yürümezoğlu \& Çökelez, 2010).

\section{Clashing Currents (Two-Component Model)}

Students believed that the current goes from positive and negative poles of battery to bulb. Currents clash in the bulb and bulb produces light (Borges \& Gilbert, 1999; Osborne, 1983; Pardhan \& Bano, 2001; Yeşilyurt, 2006; Yıldırım, Yalçın, Şensoy \& Akçay, 2008; Y1lmaz \& Huyugüzel-Çavaş, 2006).

\section{Current Consumption Model}

Students believed that the current goes from a battery to a bulb and each bulb in the circuit uses up some of the current and shares the current equally; then current decreases and returns to the battery (Borges \& Gilbert, 1999; Çepni \& Keleş, 2006; Dupin \& Johsua, 1987; Küçüközer \& Kocakülah, 2007; Osborne, 1983; Pardhan \& Bano, 2001; Yıldırım et al., 2008; Yılmaz \& Huyugüzel-Çavaş, 2006). Students thought that "The bulb uses up all of the current” (Küçüközer \& Kocakülah, 2007; Osborne, 1983; Pardhan \& Bano, 2001; Y1lmaz \& Huyugüzel-Çavaş, 2006), "The bulb uses up a little of the current" (Pardhan \& Bano, 2001), “The bulb doesn't use up the current" (Pardhan \& Bano, 2001), “All of the current returns to the battery" (Yılmaz \& Huyugüzel-Çavaş, 2006).

\section{Local and Sequential Reasoning Model}

The brightness of a bulb is affected some changes that are made before from the bulb. But some changes that are made after from the bulb doesn't affect brightness of a bulb (Küçüközer \& Kocakülah, 2007; Millar \& King, 1993; Yılmaz \& Huyugüzel-Çavaş, 2006).

\section{Emprical Rule Model}

Students believed that distance between battery and bulb affect the brightness of a bulb (Keser \& Başak, 2013; Türkoğuz \& Cin, 2013; Yılmaz \& Huyugüzel-Çavaş, 2006). The current comes from positive pole is much more than the negative pole (Bakırc1 et al., 2010; Çepni \& Keleş, 2006; Harman \& Çökelez, 2016a). Therefore, bulb that is closest to the positive pole looks much brighter than other bulbs (Pardhan \& Bano, 2001). 


\section{Constant Current Source Model}

Student believed that battery supply same current in series or parallel circuits (Cheng \& Kwen, 1998; Dupin \& Johsua, 1987; Küçüközer \& Kocakülah, 2007; Psillos, Tiberghien \& Koumaras, 1988; Yıldırım, Yalçın, Şensoy \& Akçay, 2008; Yılmaz \& Huyugüzel-Çavaş, 2006).

\section{Misconceptions on Bulb Brightness}

Harman and Çökelez (2016a) determined 5th grade students' misconceptions about the brightness of a bulb. An important part of 5th grade students had the sufficient readiness about the effects of the number of battery on the brigtness of a bulb. Some students didn't have the sufficient readiness about the effects of the number of bulb on the brightness of a bulb. When bulbs are added into a series circuit, the energy of battery is reduced and isn't sufficient, battery consumes more energy, the bulb become brighter, battery is used for a long time. When batteries are added into a series circuit, battery and bulb are used for a long time. When the number of bulbs are changed, brigtness of the bulbs don't change. Students considered that the battery is the source of light. Students believed that the negative pole of battery provides a low energy. One wire between bulb and negative or positive poles of battery is enough to complete circuit and bulb produces light. Distance between battery and bulb affect the brightness of a bulb (Harman \& Çökelez, 2016a). 7th grade students expressed that when bulbs are added into a series circuit, the bulbs become brighter (Ayvac1 \& İpekAkbulut, 2012).

Students have been thought that electricity is an abstract and a difficult topic. So that, concepts of electricity should be concreted (Yiğit \& Özmen, 2006). Analogies can be used to create concrete cases and teach of abstract topic. Analogy is a strong bridge between similar characteristics of the target and source concepts (Kesercioğlu, Yılmaz, Huyugüzel-Çavaş \& Çavaş, 2004). Analogies are given opportunities for creating the mental models of abstract concepts (Rotbain, Marbach-Ad \& Stavy, 2006). Analogies are effective for identifying and remedying misconceptions (Glynn, 1991).

\section{Hydraulic System Model (HSM)}

Hydraulic system model (HSM) can be used to teach variables affecting the brightness of a bulb in a simple electrical circuit.

Experimental activity was performed in three stages: 


\section{First Stage}

The first stage aims to establish the analogical relation between simple electrical circuit and HSM.

\section{Second Stage}

How is the brightness affected by the adding an extra battery into a series circuit?

HSM 1 and HSM 2 were compared.

When number of the bulb (plastic PET bottle) remain constant and a battery (amount of water in serum bag) is added in series circuit (in HSM), the brightness of a bulb (the height of the red ball) increases.

\section{Third Stage}

How is the brightness affected by the adding an extra bulb into a series circuit?

HSM 2 and HSM 3 were compared.

When number of the battery (amount of water in serum bag) remain constant and a bulb (plastic PET bottle) is added in series circuit (in HSM), the brightness of a bulb (the height of the red ball) decreases.

First Stage: The analogical relationship between the HSM and the simple electrical circuit are shown in Table 1.

Table 1 Analogical Relationship

\begin{tabular}{ll}
\hline HSM (Source concept) & Simple Electrical Circuit (Target concept) \\
\hline Water in the serum bag & Potential of battery \\
\hline Amount of water in serum bag & Battery \\
\hline Transparent plastic house & Connection cable \\
\hline Valve & Switch \\
\hline Plastic PET bottle & Bulb \\
\hline Height of the red ball in the plastic PET bottle & Brightness of a bulb \\
\hline
\end{tabular}




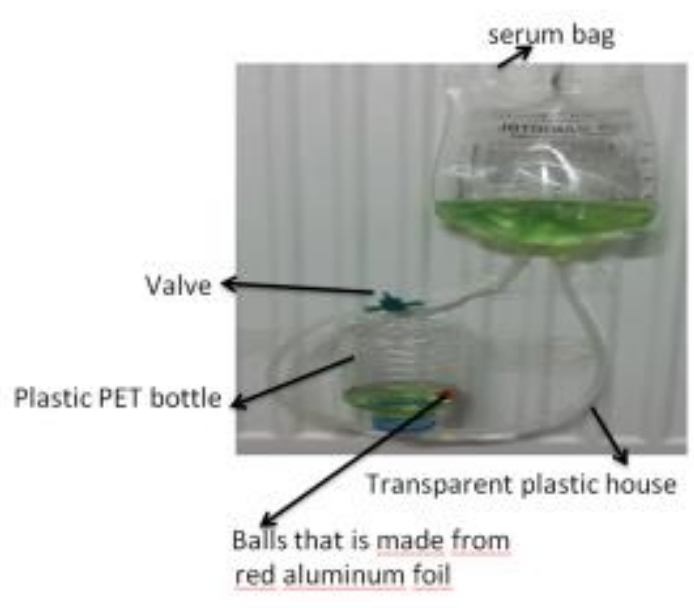

Figure 1. Hydraulic System Model (HSM)

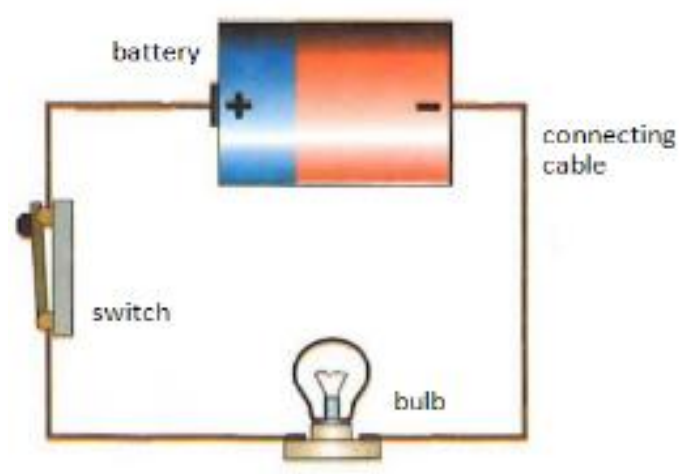

Second Stage: How is the brightness affected by the adding an extra battery into a series circuit?

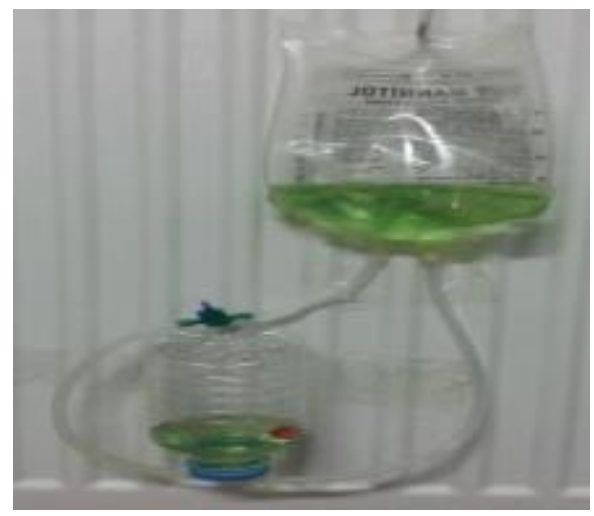

Figure 3. Hydraulic System Model 1 (HSM 1)

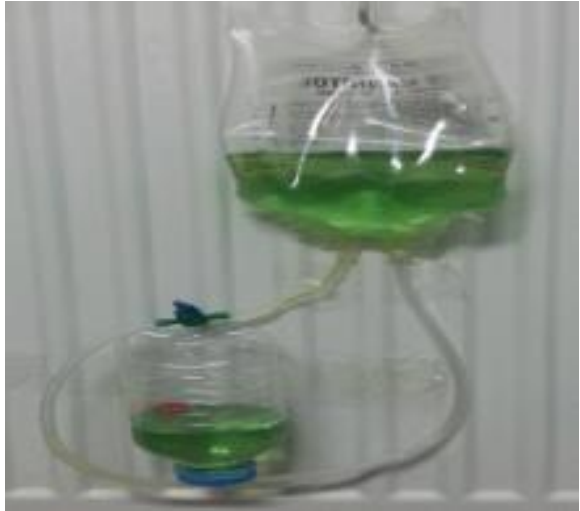

Figure 4. Hydraulic System Model 2 (HSM 2)

The tools and equipment for HSM 1 and HSM 2: 1 serum bag, transparent plastic hose, 1 valve, 1 plastic PET bottle, 1 ball that is made from red aluminum foil.

Serum bag (HSM 1) contains $150 \mathrm{~mL}$ water. Serum bag (HSM 2) contains $300 \mathrm{~mL}$ water. As a valve is opened, water flows. Water in the serum bag flows into the plastic PET bottle and the height of red ball increases. The height of the red ball is $4,5 \mathrm{~cm}$ in the HSM 1 . The height of the red ball is $6 \mathrm{~cm}$ in the HSM 2 . 
When number of the bulb (plastic PET bottle) remain constant and a battery (amount of water in serum bag) is added in series circuit (in HSM), the brightness of a bulb (the height of the red ball) increases.

Third Stage: How is the brightness affected by the adding an extra bulb into a series circuit?

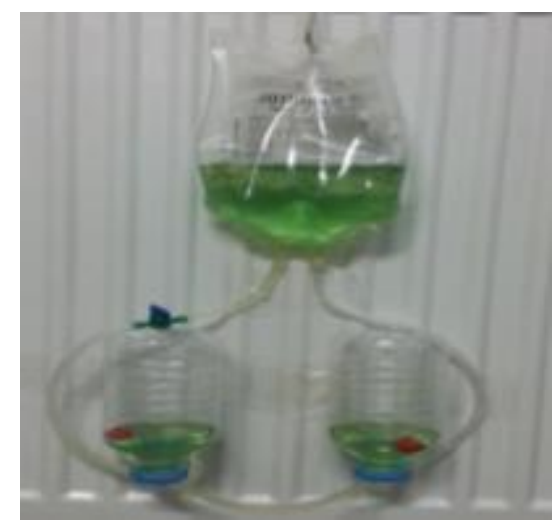

Figure 5. Hydraulic System Model 3 (HSM 3)

The tools and equipment for HSM 3: 1 serum bag, transparent plastic hose, 1 valve, 2 plastic PET bottles, 2 balls that is made from red aluminum foil.

Serum bag (HSM 3) contains $300 \mathrm{~mL}$ water. As a valve is opened, water flows. Water in the serum bag flows into the plastic PET bottle and the height of red ball increases. The height of the red balls are $4,5 \mathrm{~cm}$ in the HSM 3 .

When number of the battery (amount of water in serum bag) remain constant and a bulb (plastic PET bottle) is added in series circuit (in HSM), the brightness of a bulb (the height of the red ball) decreases.

\section{Conversion of Energy}

Students had misconceptions about energy conversion in a circuit. They considered that the battery is the source of light (Cheng \& Kwen, 1998; Harman \& Çökelez, 2016a). Therefore, information about energy conversion is given in HSM. 
Energy Conversion in a Simple Electrical Circuit

Battery converts chemical energy

directly to electrical energy.

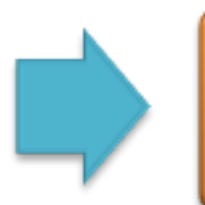

Bulb converts electrical energy to heat energy and light energy

Energy Conversion in Hydraulic System Model (HSM 1, 2, 3)
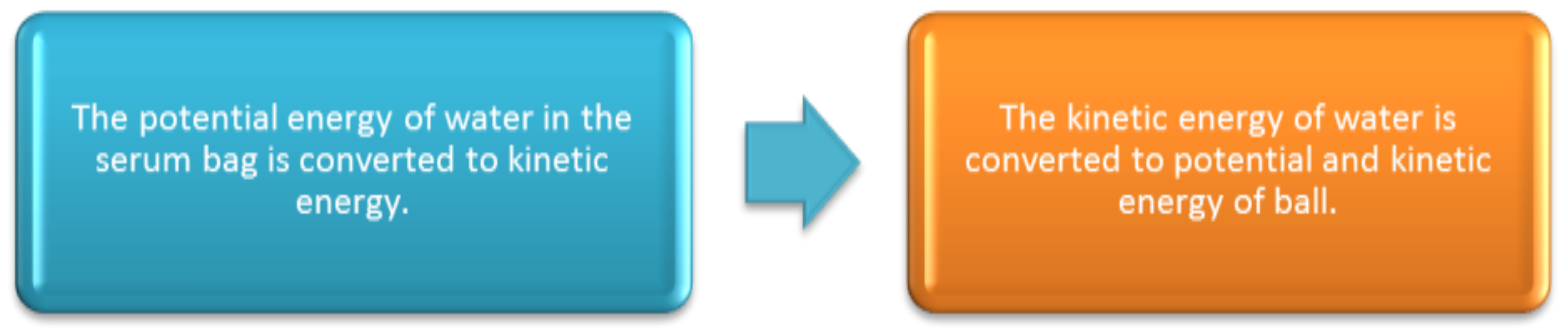

Teaching of the Dependent, Independent and Controlled Variables
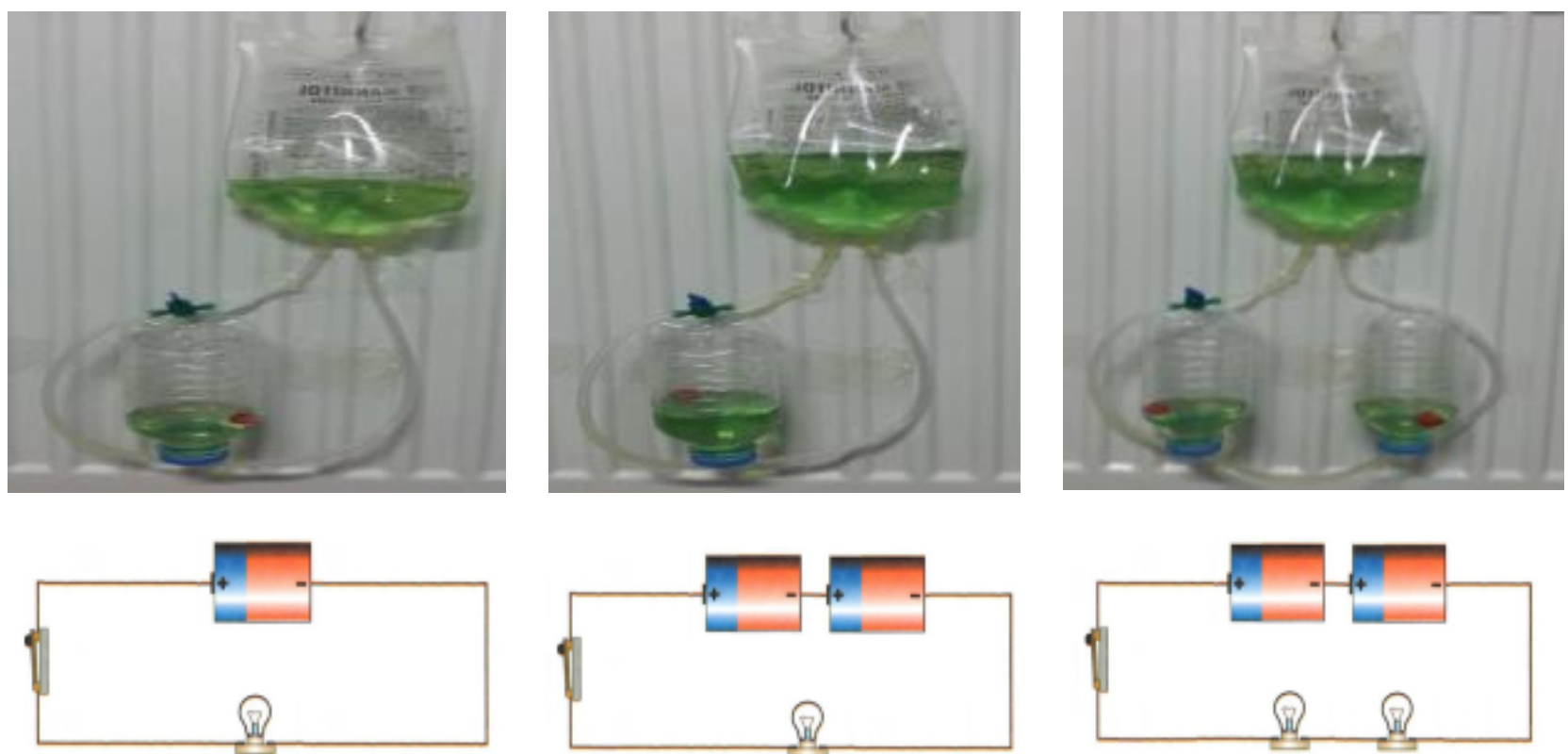

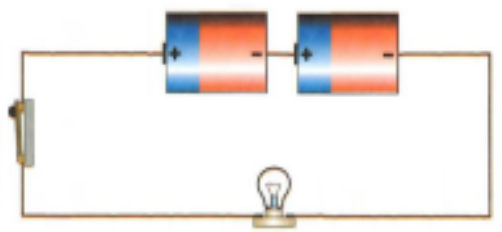

HSM 2 and SEC 2

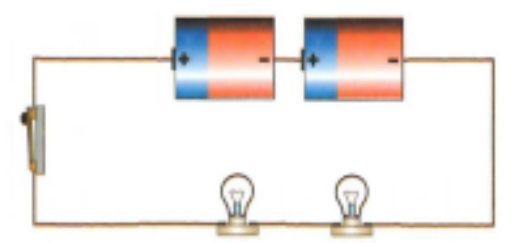

HSM 3 and SEC 3

HSM 1 and SEC 1

Figure 6. Hydraulic System Models and Simple Electrical Circuits

Dependent, independent and controlled variables in the HSM and SEC are shown in Table 2. 
Table 2 Dependent, independent and controlled variables in the HSM and SEC

\begin{tabular}{lll}
\hline Variables & HSM 1 (SEC 1) - HSM 2 (SEC 2) & HSM 2 (SEC 2) - HSM 3 (SEC 3) \\
\hline Dependent & $\begin{array}{l}\text { Height of the red balls in the plastic } \\
\text { PET bottle (Brightness of bulb) }\end{array}$ & $\begin{array}{l}\text { Height of the red balls in the plastic } \\
\text { PET bottle (Brightness of bulb) }\end{array}$ \\
\hline Independent & $\begin{array}{l}\text { Amount of water in serum bag } \\
\text { (Battery) }\end{array}$ & $\begin{array}{l}\text { Plastic PET bottle (Bulb) } \\
\text { Controlled }\end{array}$ Plastic PET bottle (Bulb) \\
\hline
\end{tabular}

Table 3 Relationship between the number of plastic PET bottle (the number of bulb), the amount of water in the serum bag (the number of battery) and height of the red ball in the plastic PET bottle (brightness of a bulb)

\begin{tabular}{llll}
\hline & $\begin{array}{l}\text { The number of } \\
\text { plastic PET bottle } \\
\text { (The number of } \\
\text { bulb) }\end{array}$ & $\begin{array}{l}\text { The amount of water } \\
\text { in the serum bag } \\
\text { (The number of } \\
\text { battery) }\end{array}$ & $\begin{array}{l}\text { Height of the red ball in the } \\
\text { plastic PET bottle } \\
\text { (The brightness of a bulb) }\end{array}$ \\
\hline $\begin{array}{l}\text { HSM1 } \\
\text { (SEC1) }\end{array}$ & $\begin{array}{l}\text { (1 plastic PET bottle } \\
(1 \text { bulb) }\end{array}$ & $\begin{array}{l}150 \mathrm{~mL} \text { water } \\
(1 \text { battery) }\end{array}$ & $4,5 \mathrm{~cm}$ \\
\hline $\begin{array}{l}\text { HSM2 } \\
\text { (SEC2) }\end{array}$ & $\begin{array}{l}\text { 1 plastic PET bottle } \\
(1 \text { bulb) }\end{array}$ & $\begin{array}{l}300 \mathrm{~mL} \text { water } \\
(2 \text { battery) }\end{array}$ & $6 \mathrm{~cm}$ \\
\hline $\begin{array}{l}\text { HSM3 } \\
\text { (SEC3) }\end{array}$ & $\begin{array}{l}\text { (2 plastic PET bottles } \\
\text { (2 bulb) }\end{array}$ & $\begin{array}{l}300 \mathrm{~mL} \text { water } \\
(2 \text { battery) }\end{array}$ & $4,5 \mathrm{~cm}+4,5 \mathrm{~cm}$ \\
\hline
\end{tabular}

\section{Differences Between Hydraulic System Model (HSM) and Simple Electrical Circuit (SEC)}

The differences between source and target concepts should be expressed for identifying and remedying misconceptions (Duit, 1991; Kesercioğlu, Yılmaz, Huyugüzel-Çavaş and Çavaş, 2004).

- The electric current returns to the battery in a simple electrical circuit. Whereas the water doesn't return to the serum bag in the HSM.

- For bulb produces light in the simple electrical circuit, the switch must be close. Whereas, for water flows into the plastic PET bottle and height of the red ball increases in the HSM, the valve must be open.

\section{Conclusions and Discussion}

HSM can be used to teach variables that affect the brightness of a bulb in a simple electrical circuit. It is thought that HSM improve scientific process skills such as prediction, observation, collecting data, performing experiments, solving problem, creating model. HSM is effective for teaching variables. HSM is effective on success, attitude, creating mental model, identifying and remedying misconceptions. 
It is found that analogies were developed on simple electrical circuit in the literature. Glynn (2008) established analogical relationship between plumbing and simple electrical circuit. Brown (1993) established analogical relationship between wagons, the movement of wagons, rails, tunnels, workers that push wagons and electric charge, electric current, wire, bulb, battery. Yılmaz and Huyugüzel-Çavaş (2006) established analogical relationship between bread bakery-battery or power supply, market-bulb or resistance, trucks-electrons, roads-electrical cabling, traffic controller-ammeter. Harman and Çökelez (2015, 2016b) established analogical relationship between Pneumatic System Model (PSM) and simple electrical circuit.

Analogical relationship were established theoretical dimension by Glynn (2008), Brown (1993) and Yılmaz and Huyugüzel-Çavaş (2006). Only, PSM is a working system. Harman and Çökelez $(2015,2016 b)$ used air pump, transparent plastic hose, valve and plastic balloon for preparing PSM. PSM and HSM contains of a simple electrical circuit, varibles affecting the brightness of a bulb and energy conversion. Others are related only simple electrical circuit.

HSM is a working and economical system in terms of time and cost. This model has been prepared with waste materials that can be easily found. Students can establish this model alone both at home and at school. I think that HSM will be effective to teach a simple electrical circuit, varibles affecting the brightness of a bulb, types of variables and energy conversion.

\section{Recommendations}

I think that analogies should be established by using materials for effective learning and teaching. Waste materials were used for preparing HSM. Therefore, HSM is important model for teaching recycling, reuse and recovery of waste material. For students understand that science can be done with waste materials and models should be prepared by using waste materials. 


\section{References}

Ayvacı, H. Ş. \& İpek-Akbulut, H. (2012). Elektrik akımı ile ilgili kavramların gelişiminde V diyagramlarının etkisini belirlemeye yönelik bir pilot çalışma. Erzincan Üniversitesi Ĕ̌itim Fakültesi Dergisi, 14(1), 109-126.

Bakırc1, H., Subay, S., Midyatlı, F., \& Ünsal, N. (2010). İlköğretim ikinci kademe öğrencilerinin bazı fen kavramlarıyla ilgili düşüncelerinin sınıf seviyesine göre incelenmesi. Abant İzet Baysal Üniversitesi Dergisi, 10(1), 31-48.

Borges, A. T. \& Gilbert, J. K. (1999). Mental models of electricity. International Journal of Science Education, 21(1), 95-117.

Brown, D. E. (1993). Refocusing core intuitions: A concretizing role for analogy in conceptual change. Journal of Research in Science Teaching, 30(10), 1273-1290.

Cheng, A. K. \& Kwen, B. H. (1998). Primary pupils' conceptions about some aspects of electricity. http://www.aare.edu.au/data/publications/1998/ang98205.pdf

Çepni, S., \& Keleş, E. (2006). Turkish Students' conceptions about the simple electric circuits. International Journal of Science and Mathematics Education, 4(2), 269-291.

Duit, R. (1991). On the role of analogies and metaphors in learning science. Science Education, 75(6), 649-672.

Dupin, J. J. \& Johsua, S. (1987). Conceptions of French pupils concerning electric circuits: Structure and evolution. Journal of Research in Science Teaching, 24(9), 791-806.

Fleer, M. (1994). Determining children's understanding of electricity. The Journal of Educational Research, 87(4), 248-253.

Glynn, S. M. (1991). Explaining science concepts: A teaching-with-analogies model. In S. Glynn, R. Yeany \& B. Britton (Eds.), The psychology of learning science (pp. 219240). Hillsdale, New Jersey: Erlbaum.

Glynn, S. M. (2008). Making science concepts meaningful to students: Teaching with analogies. S. Mikelskis-Seifert, U. Reingelband and M. Brückman (Eds.), Four decades of research in science education: From curriculum development to quality improment. (pp. 113-125). Münster, Germany: Waxmann.

Harman, G., \& Çökelez, A. (2015). Teaching the effect of variables on the brightness of a light bulb in a simple electrical circuit using a Pneumatic System Model (PSM). International Journal of Physical Sciences, 10(6), 215-221. 
Harman, G. \& Çökelez, A. (2016a). 5. sınıf öğrencilerinin lamba parlaklığı ile ilgili hazırbulunuşlukları. Turkish Studies, 11(2), 549-566.

Harman, G. \& Çökelez, A. (2016b). Pnömatik Sistem Modeli ile basit elektrik devresinde lambanın hangi durumlarda 1şık vereceğinin öğretilmesi. İlköğretim Online, 15(4), 1299-1310.

Keser, Ö. F., \& Başak, M.H. (2013). Yaşamımızdaki elektrik ünitesine yönelik öğrenci kazanım düzeylerinin incelenmesi. Türk Fen Eğitimi Dergisi, 10(2), 116-137.

Kesercioğlu, T., Yılmaz, H., Huyugüzel-Çavaş, P. \& Çavaş, B. (2004). İlköğretim fen bilgisi öğretiminde analojilerin kullanımı: “Örnek uygulamalar”. Ege Eğitim Dergisi, 5, 35-44.

Küçüközer, H., \& Kocakülah, S. (2007). Secondary school students' misconceptions about simple electric circuits. Journal of Turkish Science Education, 4(1), 101-115.

Millar, R., \& King, T. (1993). Students' understanding of voltage in simple series electric circuits. International Journal of Science Education, 15(3), 339-349.

Osborne, R. (1983). Towards modifying children's ideas about electric current. Research in Science and Technological Education, 1, 73-82.

Pardhan, H. \& Bano, Y. (2001). Science teachers' alternate conceptions about direct-currents. International Journal of Science Education, 23(3), 301-318.

Psillos, D., Tiberghien, A. \& Koumaras, P. (1988). Voltage presented as a primary concept in an introductory teaching sequence on dc circuits. International Journal of Science Education, 10(1), 29-43.

Rotbain, Y., Marbach-Ad, G., \& Stavy, R. (2006). Effect of bead and illustrations models on high school students' achievement in molecular genetics. Journal of Research in Science Teaching, 43(5), 500-529.

Türkoğuz, S., \& Cin, M. (2013). Argümantasyona dayalı kavram karikatürü etkinliklerinin öğrencilerin kavramsal anlama düzeylerine etkisi. Buca Eğitim Fakültesi Dergisi, 35, 155-173.

Yeşilyurt, M. (2006). İlköğretim ve lise öğrencilerinin elektrik kavramı ile ilgili düşünceleri. Elektronik Sosyal Bilimler Dergisi, 5(17), 41-59.

Yıldırım, H. İ., Yalçın, N., Şensoy, Ö., \& Akçay, S. (2008). İlköğretim 6., 7. ve 8. sınıf öğrencilerinin elektrik akımı konusunda sahip oldukları kavram yanılgıları. Kastamonu Ĕ̈itim Dergisi, 16(1), 67-82. 
Y1lmaz, H., \& Huyugüzel-Çavaş, P. (2006). 4-E öğrenme döngüsü yönteminin öğrencilerin elektrik konusunu anlamalarına olan etkisi. Türk Fen Ĕ̈itimi Dergisi, 3(1), 2-18.

Yiğit, N., \& Özmen, H. (2006). Fen öğretimine yönelik hazırlanan modellerin kazandırmayı amaçladıkları davranışlar açısından incelenmesi. Ondokuz Mayıs Üniversitesi Ĕ̈itim Fakültesi Dergisi, 21, 1-14.

Yürümezoğlu, K., \& Çökelez, A. (2010). Akım geçiren basit bir elektrik devresinde neler olduğu konusunda öğrenci görüşleri. Türk Fen Eğitimi Dergisi, 7(3), 147-166. 